\title{
A study of homocysteine level at the III trimester of pregnancy
}

\author{
Varuni Sharma ${ }^{1}$, Navin Shukla ${ }^{2 *}$
}

\begin{abstract}
${ }^{1}$ Department of Obstetrics and Gynecology, ${ }^{2}$ Department of ENT, M. M. Institute of Medical Sciences and Research,
\end{abstract} M.M Deemed to be University Mullana, Ambala, Haryana, India

Received: 17 May 2019

Accepted: 07 September 2019

\section{*Correspondence:}

Dr. Navin Shukla,

E-mail: drnavinshukla@yahoo.com

Copyright: () the author(s), publisher and licensee Medip Academy. This is an open-access article distributed under the terms of the Creative Commons Attribution Non-Commercial License, which permits unrestricted non-commercial use, distribution, and reproduction in any medium, provided the original work is properly cited.

\begin{abstract}
Background: Homocysteine is an amino acid which has sprung into prominence in the past few decades. Levels of maternal serum homocysteine normally decreases with gestation, either due to a physiological response to the pregnancy, increase in estrogen, haemodilution from increased plasma volume or increased demand for methionine by both the mother and fetus.

Methods: A prospective randomized controlled clinical trial of 50 patients was carried out in Kamla Raja Hospital and outpatient Department of Gajra Raja Medical College, Gwalior from October $6^{\text {th }}$ to October 2007, which was further categorized into socio-demographic and clinical factors.

Results: Out of 50 patients, it was found that there were $31(62 \%)$ cases below the age of 25 years whereas $19(38 \%)$ cases were above the age of 25 years, $30(60 \%)$ cases were educated below the primary level whereas $20(40 \%)$ cases were educated above the primary level, $10(20 \%)$ cases belonged to rural areas whereas $40(80 \%)$ cases belonged to the urban areas. According to the socio economic distribution, 11(22\%) cases were below class II whereas 39(78\%) cases were above class II. According to distribution of parity, 22(44\%) cases were below primigravida whereas 28(56\%) cases were above primigravida.

Conclusions: This study concludes that mean of Serum Levels in pregnant women with socio-demographic and clinical factors was statistically insignificant which signifies that age, education, residential areas and hemoglobin are not the factors contributing to the rise in homocysteine level in pregnant women. The diastolic and systolic blood pressure is weakly correlated with serum homocysteine level.
\end{abstract}

Keywords: Estrogen, Homocysteine level, Primigravida, Methionine, Pregnant women

\section{INTRODUCTION}

Homocysteine is a sulfur containing amino acid primarily derived from demethylation of dietary methionine, which is abundant in proteins of animal origin. It is an essential amino acid required for the growth of cells and tissues in the human body. Homocysteine is becoming increasingly recognized as an important substance in the pathogenesis. Elevated circulating homocysteine is a risk factor for endothelial dysfunction and vascular diseases such as atherosclerosis and occlusive vascular disorders. Homocysteine is an amino acid which has sprung into prominence in the past few decades. ${ }^{1}$ Elevated homocysteine levels have been shown to be deleterious on vascular endothelium. ${ }^{1,2}$ Elevated homocysteine has also served as an early marker for insulin resistance due to the effects of insulin on homocysteine metabolism and renal clearance. ${ }^{3}$ The vascular effects of hyperhomocysteinemia have proposed to include endothelial cell injury and thrombus formation. Levels of 
maternal serum homocysteine normally decreases with gestation, either due to a physiological response to the pregnancy, increase in estrogen, haemodilution from increased plasma volume or increased demand for methionine by both the mother and fetus. Homocysteine also interferes with fibrinolytic system adding to the pathophysiology of eclampsia and pre-eclampsia. ${ }^{4}$ In normal pregnancy serum homocysteine is normally decreased, due either to haemodilution incident to pregnancy or the relative deficiency during pregnancy. ${ }^{5}$ Maternal hyperhomocysteinemia has been associated with a number of pregnancy associated diseases such as pre- 17 eclampsia, placental abruption, recurrent pregnancy loss and neural tube defect in newborn.,7 Homocysteine is metabolized via two main pathways: remethylation to methionine or transulphuration to cystathionine and then to cysteine. A defect in either leads to an accumulation of circulating homocysteine. Recent reports indicate that concentrations of folate in maternal serum, plasma and red blood cells decrease from the fifth month of pregnancy onwards, and continue to decrease during the weeks after pregnancy such that by the second to third post-partum month a third of all mothers can have subnormal concentrations of folate in serum and red blood cells. ${ }^{8}$ The defect may be congenital, due to an inborn error of cystathionine-B- synthetase, or to homozygosity for a $\mathrm{C} \rightarrow \mathrm{T}$ mutation of nucleotide 677 in the methylenetetrahydrofolate reductase (MTHFR) gene.9Other reasons for mild hyperhomocysteinaemia are nutrient-related: deficiencies of folate, vitamin B12 or vitamin B6 cause homocysteine to accumulate because remethylation to methionine requires folate and vitamin $\mathrm{B} 12$, and transulphuration to cystathionine requires vitamin B6. ${ }^{10}$ Vollset et al, reported that hyperhomocysteinemia may be an important marker for, and possibly a cause of or contributor to, complications andan adverse outcome of pregnancy. ${ }^{11}$ Thus, the purpose of this study is to determine the consequences of serum homocysteine levels in pregnancy so that risk of adverse pregnancy outcomes can be reduced as many studies have stated that the rise in serum homocysteine levels is a predictive marker of adverse pregnancy outcomes.

The aim of this study is to evaluate and compare the mean Serum Levels in pregnant women with sociodemographic and clinical factors and to find the correlation of systolic blood pressure, diastolic blood pressure and hemoglobin with serum homocysteine level in pregnant women.

\section{METHODS}

A prospective randomized controlled clinical trial of 50 patients was carried out in Kamla Raja Hospital and Out Patient Department of Gajra Raja Medical College, Gwalior from October $6^{\text {th }}$ to October 2007. A total number of 50 patients were included in study and were classified into different demographic factors such as age, education, residential areas and socio-economic status.

\section{Patients eligible criteria}

Pregnant women who attended outpatient department of obstetrics and gynecology or admitted in Kamla Raja Hospital, Gwalior and the Patients who had completed 28 weeks of gestation which was calculated by absolute recall of her last menstrual period were included in the study. The pregnant women in their IIIrd trimester with singleton fetus were also included in the study whereas Patient in any of the group with medical disorder like jaundice, diabetes or any other systemic disorder were excluded from the study.

Patient included in the study group were subjected to the detailed history taking, through general and systemic examination and antenatal examination. Following investigations were sent-Hemoglobin, Urine (Albumin \& Sugar) and Serum Homocysteine. For collecting blood samples, $3 \mathrm{ml}$ blood was withdrawn from vein by syringe and poured into a vial with full aseptic precautions. Vial was immediately kept in ice box. Samples were then transferred within one hour of collection to collecting centre for estimation of serum testosterone hormone levels. Method of Direct chemiluminescence was used for estimating Serum Homocysteine levels in samples.

\section{Statistical analysis}

Data are presented as mean \pm SD. Comparison of hormonal levels between the groups was performed by unpaired student's t test and $\mathrm{p}$ value $<0.05$ was considered as statistically significant.

\section{RESULTS}

A total number of 50 patients were included in study. These patients were further categorized into different demographic factors according to their age, socioeconomic status, education and residential areas.

Table 1: Demographic distribution of patients.

\begin{tabular}{|lll|}
\hline Variable & Categories & Total cases (\%) \\
\hline \multirow{2}{*}{ Age } & $\leq 25$ years & $31(62 \%)$ \\
\cline { 2 - 3 } & $>25$ years & $19(38 \%)$ \\
\hline \multirow{2}{*}{ Education } & Below primary & $30(60 \%)$ \\
\cline { 2 - 3 } & Above primary & $20(40 \%)$ \\
\hline $\begin{array}{l}\text { Residential } \\
\text { areas }\end{array}$ & Rural & $10(20 \%)$ \\
\cline { 2 - 3 } $\begin{array}{l}\text { Socio- } \\
\text { economic } \\
\text { status }\end{array}$ & Urban & $40(80 \%)$ \\
\hline \multirow{2}{*}{ Parity } & Below class II & $11(22 \%)$ \\
\cline { 2 - 3 } & Below primigravida & $22(44 \%)$ \\
\hline
\end{tabular}

The Table 1 show the distribution of patients among different demographic factors and it was found that there were $31(62 \%)$ cases below the age of 25 years whereas $19(38 \%)$ cases were above the age of 25 years, 30(60\%) 
cases were educated below the primary level whereas $20(40 \%)$ cases were educated above the primary level, $10(20 \%)$ cases belonged to rural areas whereas $40(80 \%)$ cases belonged to the urban areas. According to the socio economic distribution, $11(22 \%)$ cases were below class II whereas 39(78\%) cases were above class II. According to distribution of parity, 22(44\%) cases were below primigravida whereas $28(56 \%)$ cases were above primigravida.

Table 2: Clinical factors.

\begin{tabular}{|ll|}
\hline Parameters & $($ Mean \pm SD deviation) \\
\hline Systolic blood pressure & $134.20 \pm 16.671$ \\
\hline Diastolic blood pressure & $87.80 \pm 13.445$ \\
\hline Serum homocysteine level & $11.3970 \pm 5.38093$ \\
\hline Haemoglobin & $8.6838 \pm 1.04248$ \\
\hline Serum bilirubin & $1.34720 \pm 0.646365$ \\
\hline
\end{tabular}

The Table 2 shows the average of the several parameters among the 50 patients. It is found that the (mean \pm SD) of systolic blood pressure is $(134.20 \pm 16.671)$, the $($ mean \pm SD) of diastolic blood pressure is $(87.80 \pm 13.445)$, the (mean $\pm \mathrm{SD})$ of serum homocysteine level is $(11.3970 \pm 5.38093)$, the (mean \pm SD) of the haemoglobin is $(8.6838 \pm 1.04248)$ and the $($ mean $\pm S D)$ of serum bilirubin is $(1.34720 \pm 0.646365)$.

The Table 3 shows the comparision of serum homocysteine level in pregnant women with respect to socio-demographic and clinical factors. It is found that the $($ mean $\pm \mathrm{SD})$ in comparision with mean serum homocysteine level, below and above the age of 25 years is (11.6726 \pm 5.84307$)$ and $10.9474 \pm 4.64475$ followed by the p-value 0.648, below and above the education of primary level is $11.5855 \pm 5.70488$ and $11.0895 \pm 4.94131$ followed by the p-value 0.755. According to the residential areas the (mean $\pm \mathrm{SD})$ of rural and urban areas is $(13.8470 \pm 7.77139)$ followed by the $p$-value 0.108 whereas the (mean $\pm \mathrm{SD}$ ) of socio economic status below and above class II is $(9.8690 \pm 3.39651)$ and $(11.7790 \pm 5.74178)$ followed by the $\mathrm{p}$-value 0.320 and the $($ mean \pm SD) of hemoglobin level is $(11.4400 \pm 5.92309)$ and (11.3922 \pm 5.39028$)$ followed by the p-value 0.985 , which shows that the results are statistically insignificant irrespective of all the variables.

Table 3: Comparision of mean of Serum Levels in pregnant women with socio-demographic and clinical factors.

\begin{tabular}{|llll|}
\hline \multirow{2}{*}{ Variable } & Categories & Serum homocysteine levels $($ mean \pm SD $)$ & p-value \\
\hline \multirow{2}{*}{ Education } & $\leq 25$ years & $11.6726 \pm 5.84307$ & 0.648 \\
\cline { 2 - 4 } & $>25$ years & $10.9474 \pm 4.64475$ & 0.755 \\
\hline \multirow{2}{*}{ Residential areas } & Below primary & $11.5855 \pm 5.70488$ \\
\cline { 2 - 4 } & Above primary & $11.0895 \pm 4.94131$ & 0.108 \\
\hline \multirow{2}{*}{ Socioi-economic status } & Rural & $13.8470 \pm 7.77139$ & 0.320 \\
\cline { 2 - 4 } & Urban & $10.7845 \pm 4.52963$ & 0.985 \\
\hline \multirow{2}{*}{ Haemoglobin level } & Below class II & $9.8690 \pm 3.39651$ & $11.7790 \pm 5.74178$ \\
\cline { 2 - 4 }
\end{tabular}

Table 4: Correlation of systolic blood pressure, diastolic blood pressure and hemoglobin with serum homocysteine levels in pregnant women.

\begin{tabular}{|l|l|l|}
\hline & $\begin{array}{l}\text { Serum } \\
\text { homocysteine level }\end{array}$ & p-value \\
\hline $\begin{array}{l}\text { Systolic blood } \\
\text { pressure }\end{array}$ & 0.430 & 0.002 \\
\hline $\begin{array}{l}\text { Diastolic } \\
\text { Blood Pressure }\end{array}$ & 0.469 & 0.001 \\
\hline Hemoglobin & 0.49 & 0.733 \\
\hline
\end{tabular}

The Table 4 shows the correlation of systolic blood pressure, diastolic blood pressure and hemoglobin with serum homocysteine level. The results have shown that the correlation coefficient of systolic blood pressure and serum homocysteine level is 0.430 followed by the $\mathrm{p}$ value 0.002 which is statistically significant. The correlation coefficient of diastolic blood pressure and serum homocysteine level is 0.469 followed by the $\mathrm{p}$ value 0.001 which is statistically significant whereas and the correlation coefficient of hemoglobin level and serum homocysteine level is 0.49 followed by the p-value 0.733 which is statistically insignificant.

\section{DISCUSSION}

The above study was conducted to evaluate and compare the mean serum levels in pregnant women with sociodemographic and clinical factors. It was found that among the 50 antenatal cases there were $31(62 \%)$ cases below the age of 25 years whereas $19(38 \%)$ cases were above the age of 25 years, 30(60\%) cases were educated below the primary level whereas $20(40 \%)$ cases were educated above the primary level, 10(20\%) cases belonged to rural areas whereas $40(80 \%)$ cases belonged to the urban areas, $11(22 \%)$ cases were below class II 
whereas $39(78 \%)$ cases were above class II. According to distribution of parity, 22(44\%) cases were below primigravida whereas $28(56 \%)$ cases were above primigravida. The variables of clinical factors have showed that the (mean \pm SD) of systolic blood pressure was $(134.20 \pm 16.671)$, the (mean \pm SD) of diastolic blood pressure was $(87.80 \pm 13.445)$, the $($ mean \pm SD) of serum homocysteine level was $(11.3970 \pm 5.38093)$, the (mean \pm SD) of the haemoglobin was $(8.6838 \pm 1.04248)$ and the $($ mean $\pm S D)$ of $S$. Bilirubin was $(1.34720 \pm 0.646365)$. The mean of serum levels in pregnant women with socio-demographic and clinical factors was statistically insignificant which signifies that age, education, residential areas and hemoglobin are not the factors contributing to the rise in homocysteine level in pregnant women. The results have also shown that the correlation coefficient of systolic blood pressure and serum homocysteine level is 0.444 followed by the $\mathrm{p}$ value 0.026 which is statistically significant.

The results have shown that the correlation coefficient of systolic blood pressure and serum homocysteine level is 0.430 followed by the p-value 0.002 which is statistically significant. The correlation coefficient of diastolic blood pressure and serum homocysteine level is 0.469 followed by the p-value 0.001 which is statistically significant whereas and the correlation coefficient of hemoglobin level and serum homocysteine level is 0.49 followed by the $p$-value 0.733 which is statistically insignificant.

The remethylation of homocysteine into the amino acid methionine is blocked by a lack of folate, which results in hyperhomocysteinaemia however, increased homocysteine concentration can be corrected easily by low-dose folate supplementation. ${ }^{12}$ Studies of atherosclerosis have shown that a graded risk of vascular disease is associated with increasing homocysteine level. ${ }^{13}$

The concentration of homocysteine in the plasma is regulated by several factors, genetic and acquired. ${ }^{14,15}$ In a metanalysis involving 420,000 patients, a $5 \mathrm{mmHg}$ difference in diastolic pressure was associated with $34 \%$ fewer strokes and $21 \%$ less coronary heart disease. ${ }^{16}$

\section{CONCLUSION}

From the above study it is concluded that the mean of serum homocysteine levels with socio-demographic and clinical factors is statistically insignificant which may be due to the small sample size. The diastolic and systolic blood pressure is weakly correlated with serum homocysteine level. Our study suggests that further studies can be acquired in order to obtain the specific results.

Funding: No funding sources Conflict of interest: None declared

Ethical approval: The study was approved by the Institutional Ethics Committee

\section{REFERENCES}

1. Forges $\mathrm{T}$, Monnier-Barbarino $\mathrm{P}$, Alberto JM, Guéant-Rodriguez RM, Daval JL, GuéantJL. Impact of folate and homocysteine metabolism on human reproductive health. Hum Reprod Update. 2007;13(3):225-38.

2. Kramer MS, Kahn SR, Rozen R. Vasculopathic and thrombophilic risk factors for spontaneous preterm birth. Int J Epidemiol. 2009;38(3):715-23.

3. Meigs JB, Jacques PF, Selhub J. Fasting plasma homocysteine levels in the insulin resistance syndrome. Diabetes Care. 2001;24(8):1403-10.

4. Sydow K, Schwedhelm E, Arakawa N, Bode-Boger SM, Tsikas D, Horning B, et al. ADMA and oxidative stress are responsible for endothelial dysfunction in hyperhomocysteinemia: Effects of Larginine and B vitamins. Cardiovasc Res. 2003;57:244-58.

5. Walker MC, Smith GN, Perkins SL, Keely EJ, Garner PR. Changes in homocysteine level in normal pregnancy. Am J Obstet Gynecol. 1999;180:660-4.

6. Ray JG, Laskin CA. Folic acid and homocysteine metabolic defects and the risk of placental abruption, pre-eclampsia and spontaneous pregnancy loss: A systemic review. Placenta. 1999;20:519-29.

7. Powers R, Evans R, Majors A. Plasma homocysteine concentration is increased in pre-eclampsia and associated with evidence of endothelial activation. Am J Obstet Gynecol. 1998;179:1605-11.

8. Ackurt F, Wetherilt H, Loker M, Hacibekiro M. Biochemical assessment of nutritional status in preand post-natal Turkish women and outcome of pregnancy. Eur J Clin Nutr. 1995;49:613-22.

9. Mudd SH, Levy HL, Skovby F. Disorders in transsulfuration. In: Scriver CR, Beaudet AL, Sly WS, Valle D, eds. The metabolic and molecular basis of molecular disease. New York: McGraw-Hill. 1995:1279-327.

10. Picciano MF. Is homocysteine a biomarker for identifying women at risk of complications and adverse pregnancy outcomes? Am J Clin Nutr. 2000;71:857-8.

11. Vollset SE, Refsum H, Irgens LM. Plasma total homocysteine, pregnancy complications and adverse pregnancy outcomes: The Hordaland Study. Am J ClinNutr. 2000;71:962-8.

12. Zhu BPl, Rolfs RT, Nangle BE, Horan JM. Effect of the interval between pregnancies on perinatal outcomes. N Engl J Med. 1999;340:589-94.

13. Selhub J, Jacques PF, Bostom AG. Association between plasma homocysteine concentrations and extracranial carotid-artery stenosis. $\mathrm{N}$ Engl J Med. 1995;332:286-91.

14. Sebastio G, Sperandeo MP, Panico M. The molecular basis of homocystinuria due to cystathionine $\beta$ synthase deficiency in Italian families and report of four novel mutations. Am $\mathbf{J}$ Hum Genet. 1995;56:1324-33. 
15. Morrison HI, Schaubel D, Desmeules M, Wigle DT. Serum folate and risk of fatal coronary artery disease. JAMA. 1996;275:1893-6.

16. MacMahon S, Peto R, Cutler J. Blood pressure, stroke, and coronary artery disease: Part 1 , prolonged differences in blood pressure: prospective observational studies corrected for the regression dilution bias. Lancet. 1990;335:765-74.

Cite this article as: Sharma V, Shukla N. A study of homocysteine level at the III trimester of pregnancy.

Int J Reprod Contracept Obstet Gynecol 2019;8:3841-5. 